\title{
Research on the Relationship between P2P Lending Platform and the Development of Small-Micro Enterprise in China
}

\author{
Zhaoyang Feng ${ }^{1}$, Xin $\mathrm{Hu}^{2}$ \\ ${ }^{1}$ Xidian University, School of Economics and Management, No.2 South Taibai Road, Xi'an Shanxi 710071, China \\ ${ }^{2}$ Xidian University, School of Economics and Management, No.2 South Taibai Road, Xi'an Shanxi 710071, China
}

\begin{abstract}
With the rapid development of P2P lending, P2P lending play an important role in small-micro enterprise financing channel. On the basis of financial function theory, the paper compares the P2P lending with other financing channel. And discusses how the P2P lending is promoting small micro-enterprise financing. Then, the author uses the panel data of seven provinces from January 2014 to September 2015 of China as sample to analyze the relationship between P2P lending and the development of small-micro enterprise. The results of the paper show that the P2P lending has a positive role in promoting the development of small-micro enterprise.
\end{abstract}

Keywords: P2P lending; Development of small-micro enterprise; Small-micro enterprise financing

\section{Introduction}

Since the first P2P lending platform-—Paipai lending has established in China, P2P lending industry has developed fast. According to the P2P lending industry portal website - The Home of P2P Lending, by the end of the February 2016, there are 3944 website platforms in P2P lending industry, and historical cumulative volume has reached 1.61 trillion RMB. Because P2P lending has an important role in improving the transparency of information, lowering transaction costs and excavating potential small-micro financial services, so it makes money flow to small-micro enterprise gradually. Sufficient funds could promote the development of small-miniature enterprise, to expand output, stimulate local consumption, and promote economic development.

On July 18, 2015, the central bank issued the guiding opinions on promoting the development of internet financial. And it has made a clear regulation that the $\mathrm{P} 2 \mathrm{P}$ lending is a person borrow money from other person through the Internet platform. The P2P lending is protected by the contract law, general principles of the civil law, and the supreme people's court judicial. The supreme people's court defines that the P2P lending platform can't have any form of guarantee, and lending interest rate shall not exceed 24 percent annual. On the legal level to make P2P lending is different from the illegal fund raise. With the establishment and gradual improvement of $\mathrm{P} 2 \mathrm{P}$ lending policies on controlling and managing system, the effect of P2P lending on economic growth is becoming more and more obvious.

\section{Literature Review}

Scholars Meyer Tet al. (2007) ${ }^{[1]}$ defines the P2P lending. Berger S and Gleisner F (2009) ${ }^{[2]}$ argue that P2P lending can improve the borrower's credit, and reduce the information asymmetry in the process of borrowing. Greiner ME and Wang, H. (2010) ${ }^{[3]}$ consider that P2P lending market must establish trust mechanism, in order to reduce information asymmetry in the process of borrowing. Lin M etal. (2013) ${ }^{[4]}$ has studied in P2P lending platform Prosper and he find that if the borrowers have rich social resources, it will be easy for him to get loans with lower costs, and the default rates of the borrowers is very low.

In recent years, there are much more papers about $\mathrm{P} 2 \mathrm{P}$ lending in China. Zhengping Zhang(2013) ${ }^{[5]}$ study the P2P lending platform on the based of operation pattern. Chao $\operatorname{Tan}(2014)^{[6]}$ have a research about the adverse selection and moral hazard in P2P lending, Jiawei Li (2015) ${ }^{[7]}$ suggest that the P2P lending is good for small-micro enterprise to get more loan. Zhaohui Li (2015) ${ }^{[8]}$ prove that the P2P lending funds in China mainly flow into small-micro enterprises.

There are so many scholars, at home or abroad, makes an extensive research on $\mathrm{P} 2 \mathrm{P}$ lending, even involved the important role of $\mathrm{P} 2 \mathrm{P}$ lending that played in small micro-enterprise financing. But it has little research about the relationship between the $\mathrm{P} 2 \mathrm{P}$ lending and small-micro enterprise's development. Therefore, this article builds the theoretical system and empirical model to analysis the relationship between the $\mathrm{P} 2 \mathrm{P}$ lending and the development of small- micro enterprise with financial functioning theory.

\section{P2P Lending Promotes the Development of Small-Micro Enterprise by Improving the Financing Environment}

In the traditional financial market, it is difficult for small-micro enterprise to get financing. There are some reasons as follow. First small-micro enterprise always exist credit risk. Most small-micro enterprises are in a small scale, poor condition, messy financial situation and lack of collateral. Secondly the small-micro enterprise is easily influenced by the economic and industry. In the economic downturn phase, small-micro enterprises may faced the situation such as marketing downturn, shortage of cash flow and badly run. Interconnection and mutual insurance is 


\section{International Journal of Science and Research (IJSR) \\ ISSN (Online): 2319-7064}

Index Copernicus Value (2015): 78.96 | Impact Factor (2015): 6.391

generally used to small-micro enterprises loan. However, this kind of loan is always with high credit risk. So the loan's cost of small-micro enterprise is much higher than large enterprises. Thirdly, the loan of small-micro enterprise is little, but the loan's program is the same. In order to control the risk of the small-micro enterprise's loan, financial institutions set a high barrier to entry. And it leads to many small micro enterprises having difficult to get the loan. In the pursuit of profit maximization, the banks are more likely to do business with large enterprises.

With the development of the Internet financial, Information has become more and more readily available, transaction costs have become less than ever. At the same time, the P2P lending makes the loan easily than before. The small-micro enterprise can get many loans from P2P lending. So money starts to flow to small-micro enterprise gradually. Now, large and medium-sized enterprises are getting loan mainly from the bank, stock market and bond market. The small-miniature enterprises can just get loan from P2P lending platform, crowdfunding and folk lending. And P2P lending is playing an important role in small-micro enterprise's loan.

(1)The advantage of P2P lending compared with bank. Interest rate of $\mathrm{P} 2 \mathrm{P}$ lending is much higher than bank, but the $\mathrm{P} 2 \mathrm{P}$ lending has the following three advantages: the first is that the operating costs of the $\mathrm{P} 2 \mathrm{P}$ lending platform are lower. The leader of Lending Club has said that the operating costs of the platform can be controlled within the half of general commercial Banks, in 2013 Internet financial summit. The second is that audit time of information is shorter, and loan deal is fast. The borrowers only need to fill out some forms. And after checked by the relevant department, the borrowers' information is put in the P2P lending platform. Generally within 1 or 2 days, the lenders can get loan. In general commercial Banks the lenders need more time. The third is that Loan funds directly from lenders to borrowers in the P2P lending platform. Borrowers and lenders are scattered. So, microfinance demand is easier to get satisfied under the same conditions.

(2)The advantage of P2P lending compared with crowdfunding.

The project sponsor gives their products or ideas, and calls for investors to participate in product production and promotion, etc. investors can gain products or money as return. We call it crowdfunding. Compared with the crowdfunding, the P2P lending has more investors, and it aimed at individuals and small-micro enterprise. And invest in crowdfunding has more risk than $\mathrm{P} 2 \mathrm{P}$ lending. Besides, investors can gain interest income more convenient from P2P lending.

(3)The advantage of P2P lending compared with folk lending. Folk lending mostly take place among acquaintances and friends. The choice of folk lending is small. Folk lending get agreement mostly with oral form or a simple IOU. Once disputes caused, it is hard to put oral form and simple IOU as a proof. Folk lending is limited by the man's quality, social experience, legal consciousness, professional ability, as well as the operation process. Compared with the folk lending, the P2P lending has more user, both investors and borrowers have more choices. Thus, it has some profits on expanding the scope of capital flows, reducing the capital idle time, reducing the cost of capital, and cutting the interest rates. Both sides of P2P lending will sign a strict legal document. If there is a dispute, the investors' right will be protected by law. It is safer in P2P lending than folk lending.

So $\mathrm{P} 2 \mathrm{P}$ lending is improving the financing environment of small- micro enterprises step by step. With the development of P2P lending, different places have different effects about the small-micro enterprises' development.

\section{The situation and tendency of P2P lending development}

\subsection{The recent development of P2P lending is stable}

In recent years, the development of $\mathrm{P} 2 \mathrm{P}$ lending has experienced the expansion type, and the $\mathrm{P} 2 \mathrm{P}$ lending is going to steadily develop in the near future. In 2014, the growth rate of volume is $268 \%$, and the volume is 14.4 times of 2012 . Now, the platform number, business scale is in a new level. In February 2016, the number of P2P lending platform has reached 1983. The whole month volume is 115.192 billion yuan, loan remaining is 317.636 billion yuan. With the administrative regulatory documents of P2P lending applied gradually, the variability of volume and loan remaining become lower (Figure 1).

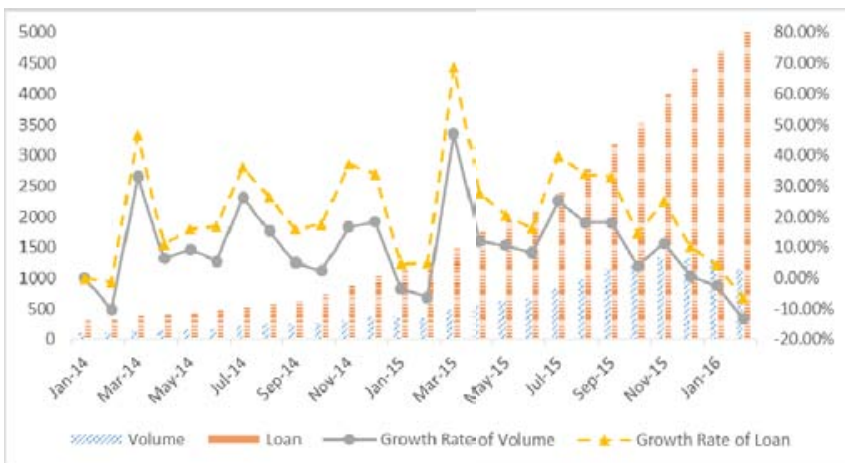

Figure 1: $\mathrm{P} 2 \mathrm{P}$ lending volume and loan remaining and its growth rate

The $\mathrm{P} 2 \mathrm{P}$ interest rate of lending is lower than before, loan date is shorter too (Figure 2). Because the central bank has turn the benchmark interest rate down. It is suggested that the P2P lending is playing an important role in interest rate transmission mechanism. P2P lending market is gradually on the regularized, healthy way. P2P lending industry provides a convenient channel for redistribution of money resources. And it is easy for small-miniature enterprise to get loan by $\mathrm{P} 2 \mathrm{P}$ lending. So small-miniature enterprise will expand output, stimulate local consumption, promote regional economic development, because of enough money. 


\section{International Journal of Science and Research (IJSR) \\ ISSN (Online): 2319-7064}

Index Copernicus Value (2015): 78.96 Impact Factor (2015): 6.391

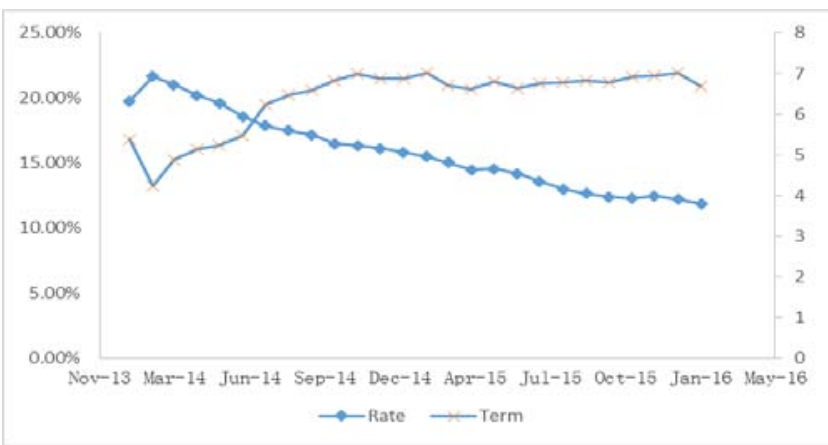

Figure 2: P2P lending average rate and average loan date

\subsection{The connection between of region P2P lending's development and its economic development}

In order to study the characteristics of regional P2P lending, this article uses six provinces (Beijing, Guangdong, Shanghai, Shandong, Sichuan and Hubei) to analysis. The P2P lending volume of Beijing and Guangdong is ahead of other provinces (Figure 3). If we take Beijing, Guangdong, Shanghai compare with Shandong, Sichuan, Hubei, we can find that the P2P lending volume of Beijing, Guangdong, Shanghai is much higher than Shandong, Sichuan, Hubei.

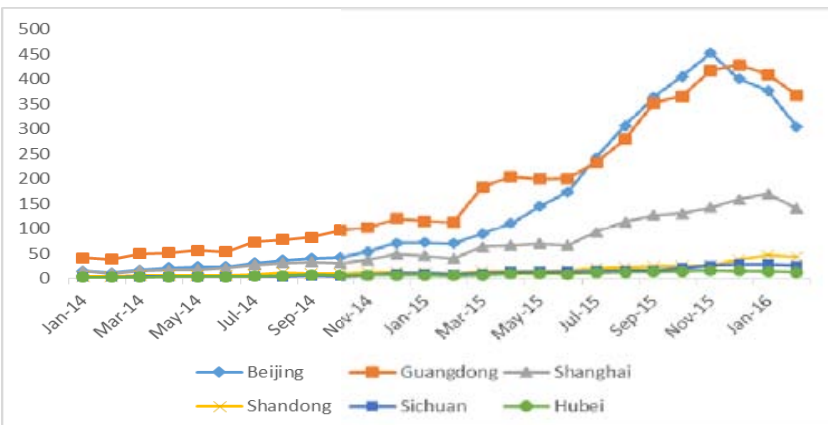

Figure 3: P2P lending volume of six provinces

From the table 1, per capita GDP and per capita retail sales of Beijing, Guangdong, Shanghai are higher than Shandong, Sichuan and Hubei. Per capita GDP is a sign of economic development and per capita retail sales is a sign of consumption. So we can see that the $\mathrm{P} 2 \mathrm{P}$ lending volume have connection with the consumption, economic development.

Table 1: The Development of Six Provinces

\begin{tabular}{|c|c|c|}
\hline Province & $\begin{array}{c}\text { Per capita retail sales in } \\
\text { 2015.1-9 (yuan) }\end{array}$ & $\begin{array}{l}\text { Per capita GDP in } \\
\text { 2015.1-9 (yuan) }\end{array}$ \\
\hline Beijing & 34990.16 & 75668.62 \\
\hline Guangdong & 21466.74 & 49344.59 \\
\hline Shanghai & 30498.72 & 73980.29 \\
\hline Shandong & 20711.56 & 47721.68 \\
\hline Sichuan & 12287.37 & 27285.52 \\
\hline Hubei & 17225.83 & 35218.85 \\
\hline
\end{tabular}

\section{Empirical Analysis of Panel Data Model}

It is difficult to quantify the development of small-micro enterprise directly, According to the small-micro enterprise development report in March 2014 China, 36.44\% of small-micro enterprises are wholesale and retail firm, $18.49 \%$ of small-micro enterprises are industry firm. The products and service from small-micro enterprises is about $60 \%$ of GDP.
The Total retail sales are mainly composed by wholesale and retail trade, catering industry and manufacturing. So The Total retail sales are strong influenced by the development of small-micro enterprise. We choose The Total retail sales to represent the development of small-micro enterprise.

(1) Sample selection and data processing

In this paper, the development of P2P lending levels is measured in two dimensions, one is development scale quantified by the volume of $\mathrm{P} 2 \mathrm{P}$ lending (LM). Another is the development quality quantified by average loan time of $\mathrm{P} 2 \mathrm{P}$ lending (LT). The total retail sales are influenced by the population and per capita disposable income. We selects the per retail sales $(\mathrm{PC})=$ total retail sales /population, in order to eliminating the influence of population factors. And put the per capita disposable income (PI) into the independent variable. Because of the limited data, the paper choose data in January 2014 to September 2015, of Beijing, Guangdong, Zhejiang, Shanghai, Jiangsu, Sichuan and China. The data of $\mathrm{P} 2 \mathrm{P}$ lending is from www.wangdaizhijia.com. The data of per retail sales and per capita disposable income is from the Office of National Statistics.

First build a regression model as follow

$$
P C_{i t}=c+\beta_{0} P I_{i t}+\beta_{1} L M_{i t}+\beta_{2} L T_{i t}+\mu_{i}+\varepsilon_{i t}
$$

Among them, $\mu$ represents unobserved potential factors unchanged with time. $\varepsilon$ represents unobserved potential factors changed with time. $i$ is the area. $\mathrm{t}$ is the month.

(2) Group unit root test on panel data

In order to avoid spurious regression problem, test the data through LLC test, IPS test, ADF-Fisher test and PP-Fisher test. The result is shown in the following table. As you can see the data of PC, PI, LM and LT has passed the group unit root test. All the data is balanced.

Table 2: The result of group unit root test

\begin{tabular}{|c|c|c|c|c|}
\hline $\begin{array}{c}\text { Testing } \\
\text { Method }\end{array}$ & $P C$ & $P I$ & LM & LT \\
\hline LLC & $-43.90^{* * *}$ & $-8.51^{* * *}$ & $-8.32^{* * *}$ & $-19.80^{* * *}$ \\
\hline IPS & $-28.21^{* * *}$ & $-5.27^{* * *}$ & $-4.66^{* * *}$ & $-19.08^{* * *}$ \\
\hline ADF-Fisher & $39.95^{* * *}$ & $17.63^{* *}$ & $18.29^{* *}$ & $31.35^{* * *}$ \\
\hline PP-Fisher & $41.77^{* * *}$ & $24.03^{* * *}$ & $23.26^{* * *}$ & $35.76^{* * *}$ \\
\hline Equation & $\mathrm{I}$ & $\mathrm{I}$ & $\mathrm{I}$ & $\mathrm{I}$ \\
\hline "**"represent the equation is significant beyond 5\%. \\
"***" represent the equation is significant beyond 1\%.
\end{tabular}

I represent the test equation is intercept.

(3) Panel data regression analysis

Choose the fixed effects model according to the characteristics of the data. Because use fixed effects model can exclude the influence of $\mu$ unobserved potential factors unchanged with time. So it can reduce endogenous errors of estimated result.

The result of the regression equation is that F-value is 37.426; $\mathrm{P}$-value is 0.000 ; the equation is significant beyond $5 \%$; $\mathrm{R}$ square is 0.898 ; adjusted R-square is 0.874 . It is suggested that the result is great. The $87.4 \%$ of dependent variable in model can be explained by the independent variable. Test results of the variables are shown in table below. PI, LM and LT 


\section{International Journal of Science and Research (IJSR) \\ ISSN (Online): 2319-7064}

Index Copernicus Value (2015): 78.96 Impact Factor (2015): 6.391

statistical is significant beyond $5 \%$.

Table 3: The test result of independent variable

\begin{tabular}{|c|c|c|c|}
\hline Independent Variable & Coefficient & t-value & $P$-value \\
\hline PI & 0.171 & 7.81 & 0.000 \\
\hline LM & 1.423 & 3.32 & 0.002 \\
\hline LT & 75.766 & 5.18 & 0.000 \\
\hline
\end{tabular}

It can be seen that per retail sales is influenced by the per capita disposable income $\mathrm{P} 2 \mathrm{P}$ lending volume and P2P lending the average loan date. The total retail sales represent the development of small-micro enterprise. So it is obvious that the $\mathrm{P} 2 \mathrm{P}$ lending is promoting the small-micro enterprise development.

\section{Summary and Advice}

Comprehensive theoretical and empirical results, the $\mathrm{P} 2 \mathrm{P}$ lending have indispensable role on regional economic development as the supplement of the traditional financial institutions. The P2P lending is more suitable for small-micro enterprise. So the money from $\mathrm{P} 2 \mathrm{P}$ lending is mainly flowing into small-micro enterprise. It alleviates the financing problem of small-micro enterprise, and promotes the development of small-micro enterprise. Because of the lack of good credit reporting system, industry barrier, regulatory agencies and regulatory mechanism, many $\mathrm{P} 2 \mathrm{P}$ lending platform has close down. It hurt the investor's confidence about P2P lending.

Based on the status of $\mathrm{P} 2 \mathrm{P}$ lending industry, the article put forward to some suggestions as following:

1) Share information of bad accommodators among $P 2 P$ lending platform, strengthen the construction of credit system for P2P lending industry.

2)Use big data technology step by step to make trade on P2P lending platform more safety and convenient.

3) The government should integrate the bank credit reporting system and open it to the P2P lending, strengthen the construction of individual and small-micro enterprise credit system

4) Improve the regulatory mechanism on P2P lending industry, strengthen the regulation of the $\mathrm{P} 2 \mathrm{P}$ lending to reduce the crime about $\mathrm{P} 2 \mathrm{P}$ lending platform and enhance the investor confidence.

\section{References}

[1] R. Meyer, T. , Heng, S. , Kaiser. S. , and Walter, N, Online P2P Lending Nibbles at Banks' Loan Business, Deutsche Bank Research, 2007.

[2] A. Greiner, M. E. and Wang, H. "Building Consumer to - consumer Trust in E - finance Marketplaces: An Empirical Analysis. " International Journal of Electronic Commerce, II (1), pp. $105-136,2010$.

[3] A. Berger, S. C. , and Gleisner, F, "Emergence of Financial Intermediaries in Electronic Markets: The Case of Online P2P Lending. " Bur Business Research Journal, XVII (2), pp. $39-65.2009$.

[4] A. Lin, M. , Prabhala, N. R. , and Viswanathan, S. “ Judging Borrowers by the Company they Keep: Friendship Networks and Information Asymmetry in Online Peer - to
- peer Lending.” Management Science, LIX (1), pp. 17 -35. 2013.

[5] A. Zheng-ping Zhang and Xia-lu Hu. "P2P Online Lending: International Development and Practice in China. " Journal of Beijing Technology and Business University, XXVIII (2), pp. 87 -94. 2013.

[6] A. Chao Tan, Jining Wang and Benzhi Sun. "Research on Adverse Selection and Moral Hazard in the P2P Online Lending Platform." Journal of Finance and Economics, XXVIIII (5), pp. $100-108.2014$.

[7] A. Jiawei Li and Sixian Feng. " Research on Reducing the Cost of Small-Micro Enterprise's financing in P2P Lending.” Inquiry into Economic Issues, LIII (2), pp. 147 $-150.2015$.

[8] A. Zhaohui Li. "Research on the Relationship between P2P Lending Platform and Small-Micro Enterprise's financing.” Modern Economic Research, VIIII (2), pp. 43 $-47.2015$.

\section{Author Profile}

Zhaoyang Feng is reading the M.S. degrees in Xidian University. 